\title{
Purification and Characterization of Beta-Amylase of Bacillus subtilis Isolated from Kolanut Weevil
}

\author{
Femi-Ola Titilayo Olufunke (Corresponding author) \\ Department of Microbiology, Ekiti State University, P.M.B. 5363, Ado- Ekiti, Nigeria \\ Tel: 234-806-661-3611Ｅ-mail: titifemi2006@yahoo.com
}

Ibikunle Ibidapo Azeez

Department of Microbiology, Ekiti State University, P.M.B. 5363, Ado- Ekiti, Nigeria

Tel: 234-803-660-6156 E-mail: ibidapoibikunle@ gmail.com

Received: July 21, 2012 Accepted: August 3, 2012

doi:10.5296/jbls.v4i1.2595 URL: http://dx.doi.org/10.5296/jbls.v4i1.2595

\begin{abstract}
An extracellular beta amylase was induced in cultures of Bacillus subtilis isolated from the kolanut weevil, Balanogastris kolae grown in liquid medium that contained kolanut starch as sole carbon source. The enzyme was partially purified 1.28 -fold by acid treatment with ice cold 1.0N HCl and 6.4-fold by gel filtration with Sephadex G-150. The beta amylase had a molecular weight of $39.4 \mathrm{kDa}$. The enzyme had its optimal activity at $\mathrm{pH} 5.0$ and exhibited maximal activity at temperature of $50^{\circ} \mathrm{C}$. The activity of the enzyme was enhanced by $\mathrm{Na}^{+}$, $\mathrm{Ca}^{2+}$ and ethylene diaminetetraacetic acid (EDTA), while $\mathrm{Hg}^{2+}, \mathrm{Mg}^{2+}$ and $\mathrm{Fe}^{2+}$ acted as inhibitors of its activity. The beta amylase had an apparent Michaelis constant $\mathrm{K}_{\mathrm{m}}$ of 5.0 $\mathrm{mg} / \mathrm{ml}$ and maximum velocity $\left(\mathrm{V}_{\max }\right)$ of $50 \mathrm{U} / \mathrm{mg}$ proteins.
\end{abstract}

Keywords: Beta-amylase, Bacillus, Kola nut, Starch, Inhibitors, Molecular weight.

\section{Introduction}

Amylases constitute a class of industrial enzymes which alone form $25 \%$ of the enzymes market covering industrial processes such as brewing sugar, textile, paper, distilling industries and pharmaceuticals (Mamo et al., 1999; Pandey et al., 2000; Oudjeriouat et al., 2003). Amylases are employed in the conversion of starch into different sugar solutions (Pandey et al., 
2000; Ray, 2000; Obineme et al., 2003). The enzymes involved are mainly $\alpha$-amylase $(1,4$ $\alpha$-glucan glucaohydrolase, EC3.2.1.1), $\beta$ - amylase (1,4 $\alpha$-glucan maltohydrolase, EC 3.2.1.2) and glucoamylase (1,4 $\alpha$-glucan glucohydrolase, EC 3.2.1.3) (Boldon and Effront, 2000). Though amylases originates from different sources such as plants, animals and microorganisms, the microbial amylases are the mostly produced and used in industry due to their productivity and thermo stability (Reddy et al., 2003). Unlike other members of the amylase family, only a few attempts have been made to study $\beta$ - amylases particularly of plant origin while there is a dearth on information on $\beta$ - amylase from microbial sources. Bacterial strains belonging to the genera Bacillus, Pseudomonas, Clostridium (Ray, 2000; Rani et al., 2007); and fungal strains belonging to Rhizopus (Forgarty and Kelly, 1990) and Volvariella volvacea (Olaniyi et al., 2010) have been reported to synthesize $\beta$ - amylase. In plant, $\beta$ - amylase is distributed in higher plants such as soybean, sweet potato, barley (Chang et al., 1996; Oudjeriouat et al., 2003). The properties of the $\beta$ - amylase varies from one source to the other. Some of the microorganisms reported to produce $\beta$ - amylase has employed starchy wastes such as cassava, rice husk, potato rice and maize as substrates for production. This present study describe the properties of the $\beta$ - amylase produced by a Bacillus subtilis strain isolated from the gut of kola nut weevil Balanogastris kolae (Desbr.) when grown in a basal medium containing kola nut starch as carbon source.

\section{Materials and Methods}

\subsection{Collection of Sample}

Kola nut sample (Cola acuminata) was purchased from the King's market square, Iragbiji, Osun- State, Nigeria.

\subsection{Proximate Analysis of Kola Nut}

Various parameters such as moisture content, ash content, crude fibre, crude protein, crude fat and carbohydrate contents were determined by the standard methods of the Association of Official Analytical Chemists (AOAC, 1984). The kola nuts were cured by traditional method of wrapping in fresh banana leaves to reduce moisture loss. The moisture content was determined by heating $2.0 \mathrm{~g}$ of each triplicate sample to a constant weight in a crucible placed in an oven maintained at $105^{\circ} \mathrm{C}$. The dry matter was used in the determination of the other parameters. Crude protein was determined by the Kjeldahl method, using $2.0 \mathrm{~g}$ samples. Crude fat was obtained by exhaustively extracting $5.0 \mathrm{~g}$ of each sample in a Soxhlet apparatus using petroleum ether (boiling point range $40-60^{\circ} \mathrm{C}$ ) as the extractant.

Ash content was determined by the incineration of $10.0 \mathrm{~g}$ samples placed in a muffle furnace maintained at $550^{\circ} \mathrm{C}$ for $5 \mathrm{~h}$. Crude fibre was obtained by digesting $2.0 \mathrm{~g}$ of sample with $\mathrm{H}_{2} \mathrm{SO}_{4}$ and $\mathrm{NaOH}$ and incinerating the residue in a muffle furnace maintained at $550^{\circ} \mathrm{C}$ for $5 \mathrm{~h}$. Total carbohydrate was obtained by difference.

\subsection{Organism and Culture Conditions}

The isolate of Bacillus subtilis used for this research was from kolanut weevil Balanogastris kolae Desbr. The organism was grown in a basal medium containing (g/l): $\mathrm{K}_{2} \mathrm{HPO}_{4}, 2.5$; 
$\mathrm{KH}_{2} \mathrm{PO}_{4}, 3.75 ; \mathrm{MgSO}_{4}, 0.125 ; \mathrm{NaCl}, 3.75 ;\left(\mathrm{NH}_{4}\right)_{2} \mathrm{SO}_{4}, 2.5 ; \mathrm{CaCl}_{2} .2 \mathrm{H}_{2} \mathrm{O}, 0.05 ; \mathrm{FeSO}_{4} .7 \mathrm{H}_{2} \mathrm{O}$ 0.05 ; yeast extract, 1.25 and cocoyam starch, 2.5. The inocula for the experiments were prepared by growing the organism in nutrient broth $\left(\mathrm{NB}\right.$, Oxoid) at $35^{\circ} \mathrm{C}$ for $18 \mathrm{hrs}$ on a rotary shaker (Gallenkamp). Sterilized medium $(500 \mathrm{ml})$ in $1000 \mathrm{ml}$ conical flasks was inoculated with $5 \mathrm{ml}$ of inocula containing $1.25 \times 10^{5}$ cells $\left./ \mathrm{ml}\right)$. The flask was incubated at $35^{\circ} \mathrm{C}$ on a rotary shaker (120 r. p. m) for $48 \mathrm{hrs}$ and then centrifuged at 5000 r. p. $\mathrm{m}$ for $20 \mathrm{mins}$ in cold to remove bacterial cells. The supernatant obtained was used as the crude extract for further studies.

\subsection{Amylase Assay}

Amylase activity was estimated by the 3, 5 Dinitrosalicyclic acid (DNSA) method of Bernfield (1955). It measures the increase in the reducing power of the digests in the reaction between starch and the enzyme. Appropriately diluted $0.5 \mathrm{ml}$ of enzyme was added to $0.5 \mathrm{ml}$ of $1 \%(\mathrm{w} / \mathrm{v})$ soluble starch which was dissolved in appropriate buffer solution (phosphate buffer, 6.9). The above reaction mixture was made in three test tubes. The reaction tubes were incubated at room temperature for 3 minutes. Then one $\mathrm{ml}$ of colour reagent (DNSA) was added to the reaction mixture and place in boiling water bath (Gallenkamp) for 5 mins. The tubes were allowed to cool at room temperature. After which $10 \mathrm{ml}$ of distilled water was further added to the cooled tubes and absorbance at 540nm was measured using spectrophotometer (Jenway, 6305). Control tube consisted of $0.5 \mathrm{ml}$ buffer solution plus $0.5 \mathrm{ml}$ soluble starch solution. The assay was also carried out as explained above. All assays were done in triplicates. The amount of maltose liberated was extrapolated from the maltose standard curve. One unit of beta amylase activity was defined as the amount of enzyme required to produce one micromole of maltose from starch under the assay condition. That is, amount of the enzyme which releases one micromole of maltose from the starch in 3 mins.

\subsection{Protein Determination}

Protein was determined by the Biuret method of Lowry et al. (1951) with bovine serum albumin (BSA) as the standard. The concentration of protein during purification studies was measured at an absorbance of $280 \mathrm{~nm}$.

\subsection{Purification and Characterization of Beta Amylase}

\subsubsection{Acid Treatment}

Fifty millilitres $(50 \mathrm{ml})$ of crude enzyme at a $\mathrm{pH}$ of 4.7 was adjusted to $\mathrm{pH} 3.6$ with ice cold $1.0 \mathrm{~N} \mathrm{HCl}$. This was allowed to stand for 10 minutes. The acidified enzyme was readjusted to $\mathrm{pH} 4.7$ with $3 \% \mathrm{NH}_{4} \mathrm{OH}$ solution. The acid treated sample was concentrated overnight in cold $4.0 \mathrm{M}$ sucrose solution at $4^{\circ} \mathrm{C}$.

\subsubsection{Gel Filtration Chromatography (using Sephadex G-150)}

Sephadex G-150 was swollen in 0.015M acetate buffer at $\mathrm{pH} 4.7$ for 3 days before it was packed into column. Forty millilitres of the acid treated fraction was applied to a Sephadex G-150 (Pharmacia) column $(1.5 \times 75 \mathrm{~cm})$ which had been previously equilibrated with $0.015 \mathrm{M}$ $\mathrm{NaHPO}_{4}$ buffer, $\mathrm{pH} 4.7$. The column was eluted with the same buffer at a flow rate of $20 \mathrm{ml} / \mathrm{hr}$. A fraction of $5.0 \mathrm{ml}$ were collected at interval of $30 \mathrm{mins}$ and the absorbance at $280 \mathrm{~nm}$ was 
read using spectrophotometer (Jenway, 6305). Fractions with amylase activity were pooled and concentrated in glycerol solution at $30^{\circ} \mathrm{C}$.

\subsubsection{Determination of Molecular Weight}

The apparent molecular weight of the beta amylase was estimated from the gel filtration column using alpha chymotrypsinogen $(25.7 \mathrm{kDa})$, ovalbumin $(45 \mathrm{kDa})$, bovine serum albumin (68 kDa), creatine phosphokinase $(81 \mathrm{kDa})$ and Gamma Globulin (150 kDa) (Sigma, $\mathrm{UK})$ as reference proteins.

\subsubsection{Effect of Temperature on Beta-amylase Activity and Stability}

Beta amylase activity was assayed by incubating the enzyme reaction mixture at different temperatures $\left(20^{\circ} \mathrm{C}\right.$ to $\left.80^{\circ} \mathrm{C}\right)$ for 3 mins. The thermal stability at $70^{\circ} \mathrm{C}$ and $80^{\circ} \mathrm{C}$ was also determined. Samples were taken at $5 \mathrm{mins}$ intervals and assayed for amylolytic activity.

\subsubsection{Effect of $\mathrm{pH}$ on Beta-amylase Activity}

Buffer $(0.05 \mathrm{M})$ of different $\mathrm{pH}$ ranging from 3.0 to 8.0 were prepared using different buffer system, Glycine-HCl, pH 3.0; acetate buffer, $\mathrm{pH} 4.0$ and 5.0; phosphate buffer $\mathrm{pH} 6.0$ and 7.0; Tris- $\mathrm{HCl}, \mathrm{pH}$ 8.0. Each of this buffer solution was used to prepare $1 \%$ soluble starch solution used as substrate in assaying the enzyme. The assay was carried out according to standard assay procedure.

\subsubsection{Effect of Substrate Concentration and Determination of Kinetic Parameters}

The effect of substrate concentration [S] on the rate of enzyme action was studied using [S] values of $2.0 \mathrm{mg} / \mathrm{ml}$ to $10.0 \mathrm{mg} / \mathrm{ml}$. The Lineweaver-Burke plot was made. Both the maximum velocity $\left(\mathrm{V}_{\max }\right)$ and Michaelis - Menten constant $\left(\mathrm{K}_{\mathrm{m}}\right)$ of the enzyme were calculated.

\subsubsection{Effect of Heavy Metals on Enzyme Activity}

A stock solution of $0.01 \mathrm{M}$ of $\mathrm{HgCl}_{2}$ and EDTA were prepared. Two milliliter of each salt solution was mixed with $2 \mathrm{ml}$ of enzyme solution. The mixture was incubated for $5 \mathrm{mins}$ at room temperature. A $0.5 \mathrm{ml}$ of the mixture was withdrawn and assay according to standard assay procedure.

\subsubsection{Effect of Cations}

A stock solution of $0.01 \mathrm{M}$ of each salt was prepared. The salts used were $\mathrm{NaCl}, \mathrm{CaCl}_{2}, \mathrm{FeCl}_{2}$ and $\mathrm{MgCl}_{2}$. Two milliliter of salts solution was mixed with $2 \mathrm{ml}$ of enzyme solution. And the same procedure for heavy metals was followed.

\section{Analysis of Results}

The result of the proximate analysis of kola nut is shown on Table 1 . The carbohydrate content was $67.49 \%$. The percentage of other parameters were moisture content, $11.48 \%$; crude protein, 9.98\%; fat, $5.88 \%$ and crude fibre, $1.89 \%$. 


\section{Macrothink}

Table 1. Proximate composition of Cola acuminata

\begin{tabular}{|l|l|}
\hline Samples & Composition (\%) \\
\hline Moisture content & 11.48 \\
\hline Ash & 3.28 \\
\hline Crude fibre & 1.89 \\
\hline Crude protein & 9.98 \\
\hline Fat & 5.88 \\
\hline Carbohydrate content & 67.49 \\
\hline
\end{tabular}

The partial purification profile of the extracellular beta amylase produced by Bacillus subtilis is summarized in Table 2. The two step purification process revealed a specific activity of 3.01 units $/ \mathrm{mg}$, yield of $42.16 \%$ and fold equals 6.40 . The elution profile of the enzyme on Sephadex G- 150 gel filtration column showed a single peak of amylase activity (Fig. 1). The molecular weight of the $\beta$ - amylase was estimated to be $39.4 \mathrm{kDa}$. The purified enzyme exhibited maximum activity at $50^{\circ} \mathrm{C}$ (Fig. 2) and $\mathrm{pH} 5.0$ (Fig. 3). The enzyme was partially stable at $70^{\circ} \mathrm{C}$ as it retained about $50 \%$ of its activity after when heated for 30 minutes (Fig.4). At this temperature, the enzyme was gradually denatured, losing its approximately $80 \%$ of its activity after 120 minutes. A Lineweaver-Burke plot of the purified $\beta$ - amylase activity of $B$. subtilis (Fig.5), indicates that this enzyme has apparent $\mathrm{K}_{\mathrm{m}}$ and $\mathrm{V}_{\max }$ values for the hydrolysis of soluble starch of $5.0 \mathrm{mg} \mathrm{ml}^{-1}$ and $50.0 \mathrm{U}$ respectively. The activity of beta amylase was stimulated by $\mathrm{Na}^{+}, \mathrm{Ca}^{2+}$ and EDTA, while its activity was mildly inhibited by $\mathrm{Mg}^{2+}$. However $\mathrm{Fe}^{2+}$ strongly inhibited the activity of the $\beta$ - amylase (Table 3 ).

Table 2. Purification of extracellular $\beta$ - amylase of Bacillus subtilis

\begin{tabular}{|lcccccc|}
\hline Fraction & $\begin{array}{c}\text { Vol. } \\
(\mathrm{ml})\end{array}$ & $\begin{array}{c}\text { Protein } \\
\text { Content } \\
(\mathrm{mg} / \mathrm{ml})\end{array}$ & $\begin{array}{c}\beta \text {-amylase } \\
\text { activity } \\
(\mathrm{U})\end{array}$ & $\begin{array}{c}\text { Specific } \\
\text { activity } \\
(\mathrm{U} / \mathrm{mg} \text { of protein })\end{array}$ & $\begin{array}{c}\text { Yield } \\
(\%)\end{array}$ & $\begin{array}{c}\text { Purification } \\
\text { fold }\end{array}$ \\
\hline Crude enzyme & 50 & 1001 & 479 & 0.47 & 100 & 1.00 \\
Acid & & & & & & \\
treatment & 50 & 598 & 879 & 1.47 & 59.74 & 1.28 \\
Gel Filtration & 40 & 422 & 1270 & 3.01 & 42.16 & 6.40 \\
\hline
\end{tabular}




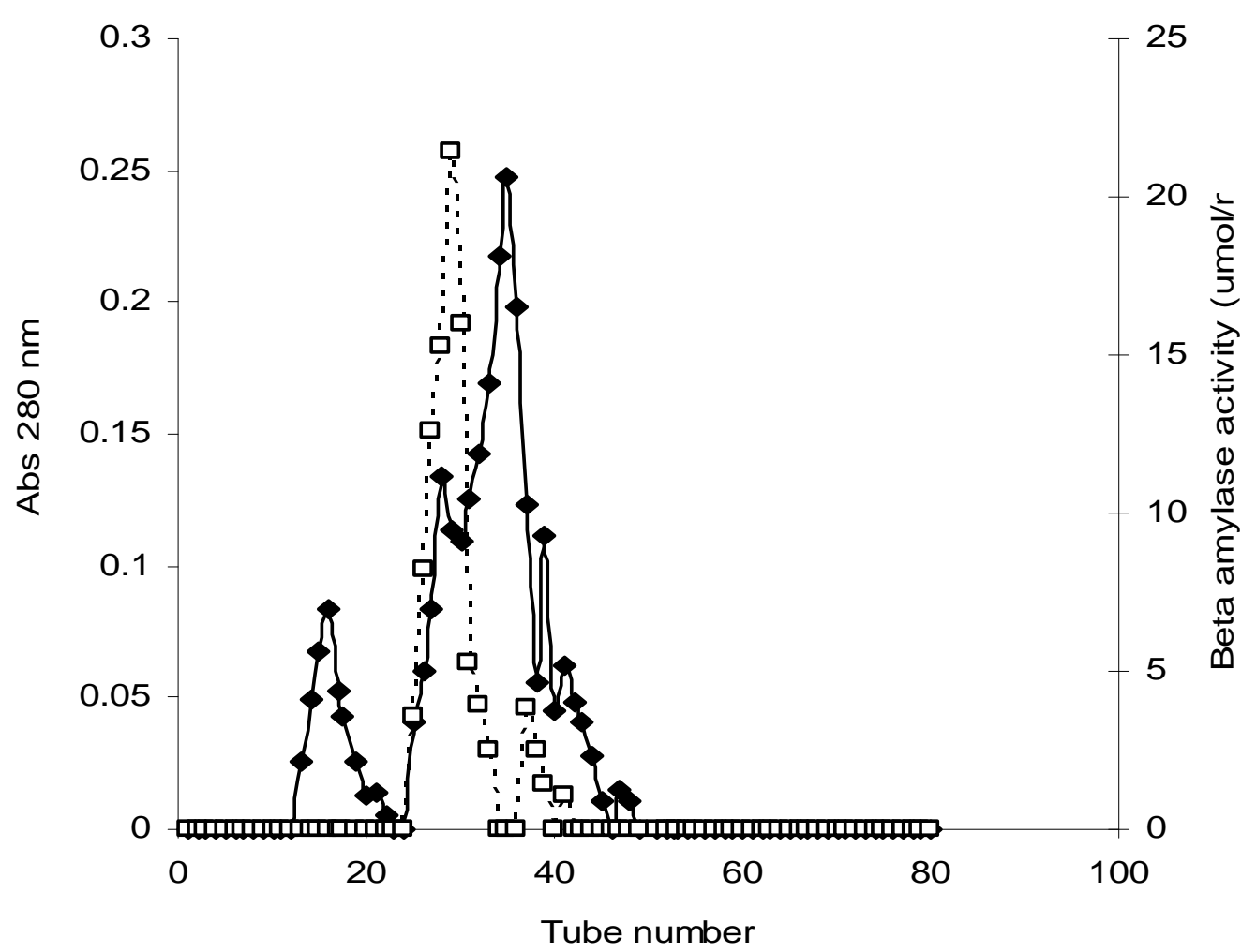

Figure 1. Elution profile of $\beta$-amylase produced by Bacillus sp. grown in production media using sephadex $\mathrm{G}-150$ (1.5 x 75) column equilibrated with $0.015 \mathrm{M}$ acetate buffer, $\mathrm{pH} 4.7$.

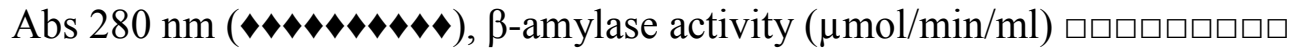

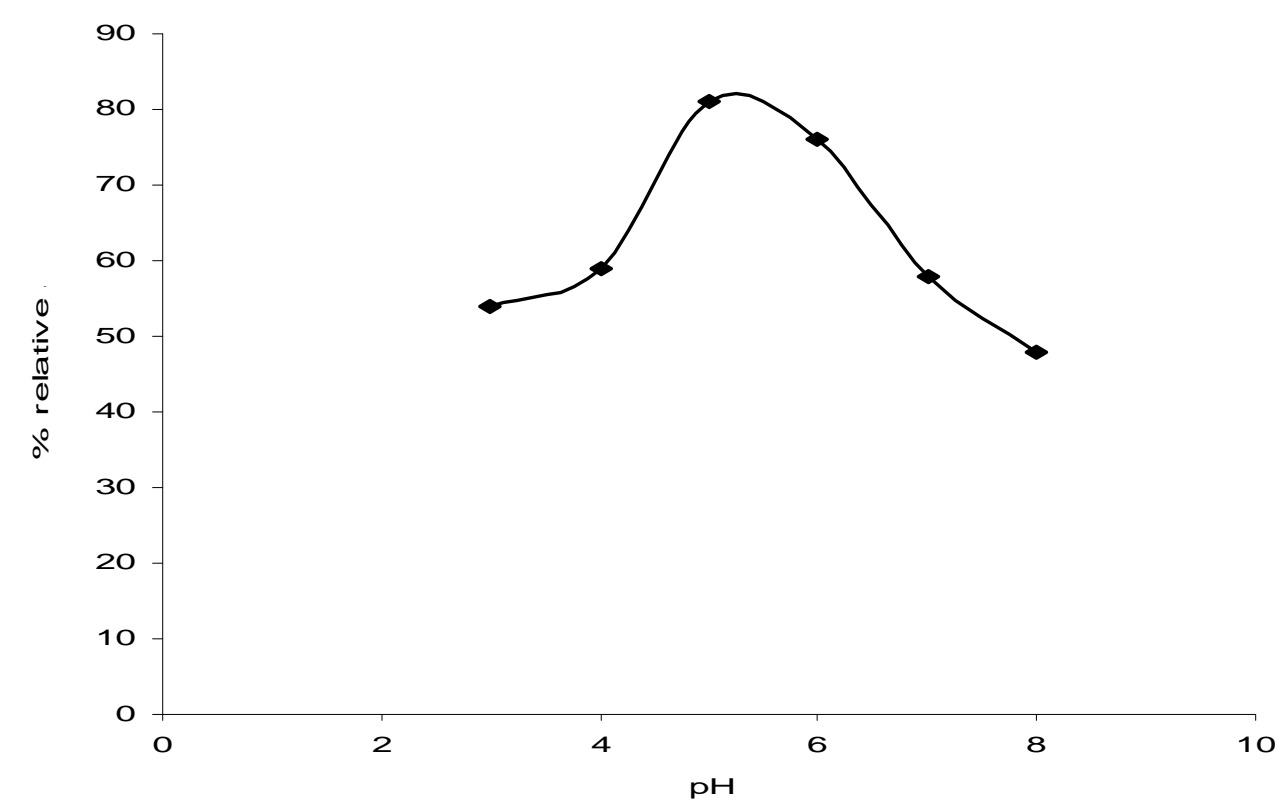

Figure 2. Effect of $\mathrm{pH}$ on $\beta$-amylase activity of Bacillus sp grown in production media. 


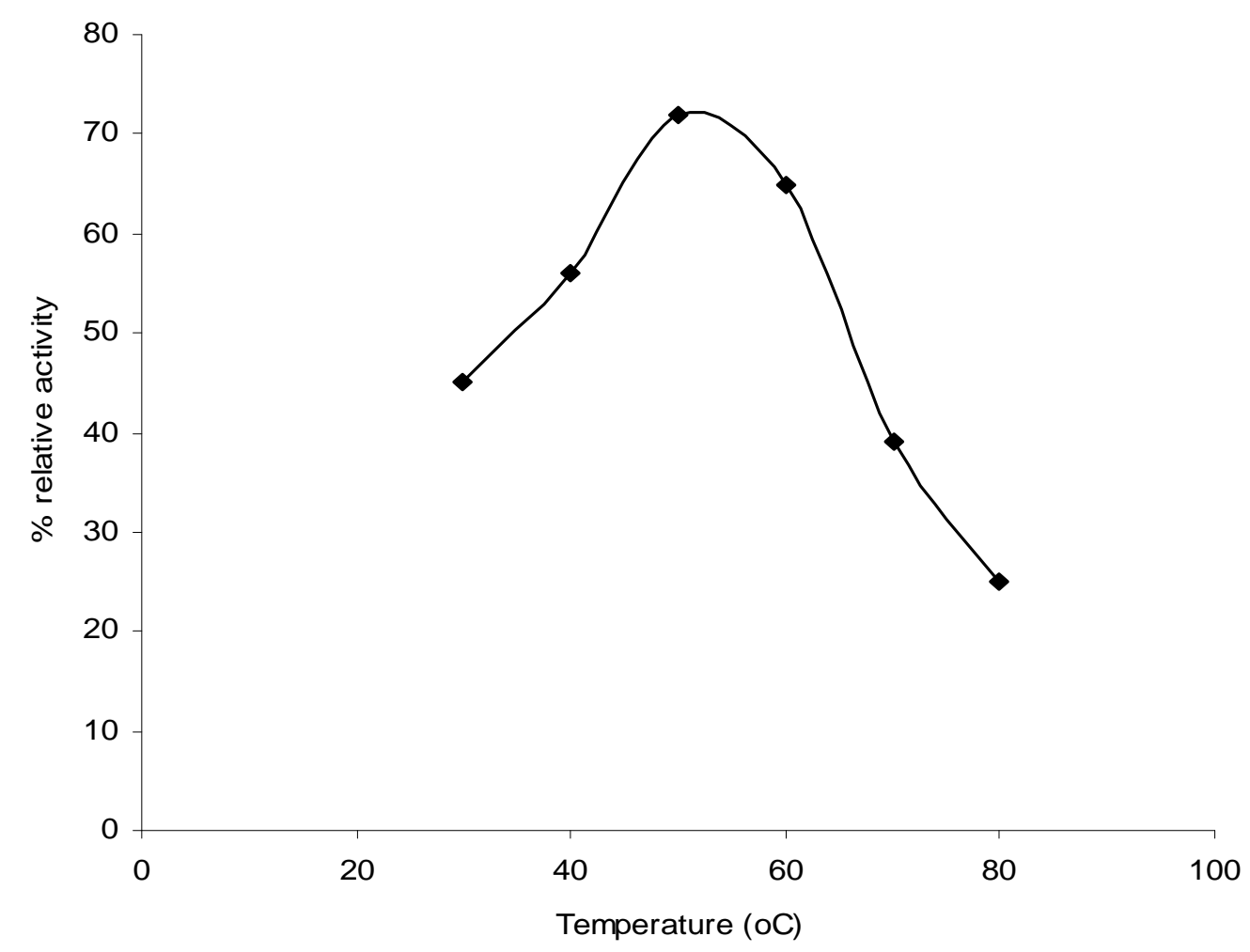

Figure 3. Effect of temperature on $\beta$-amylase activity of Bacillus sp. grown in production media.

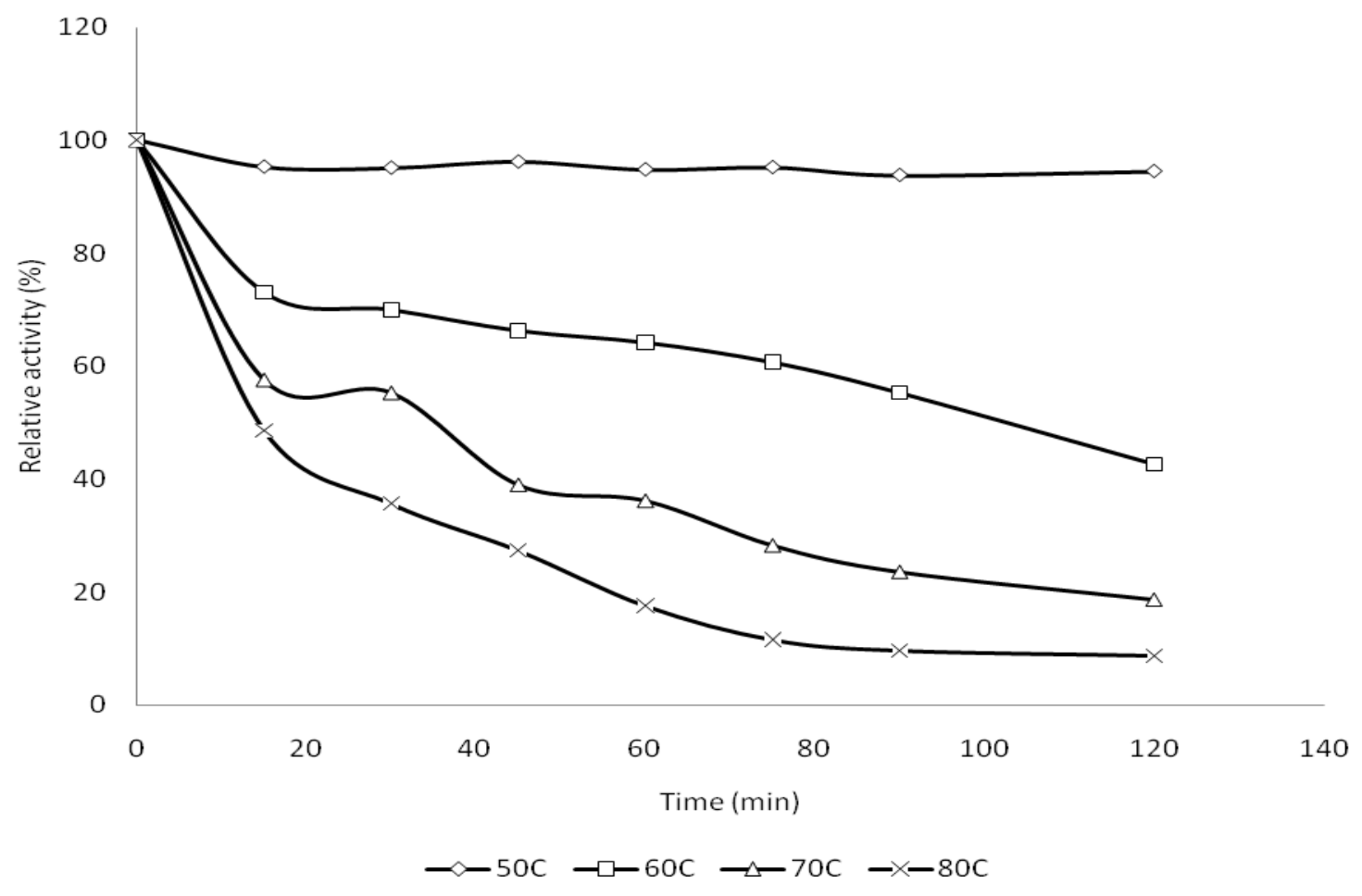

Figure 4. Thermal stability of $\beta$-amylase produced by Bacillus sp. in a growth medium. 


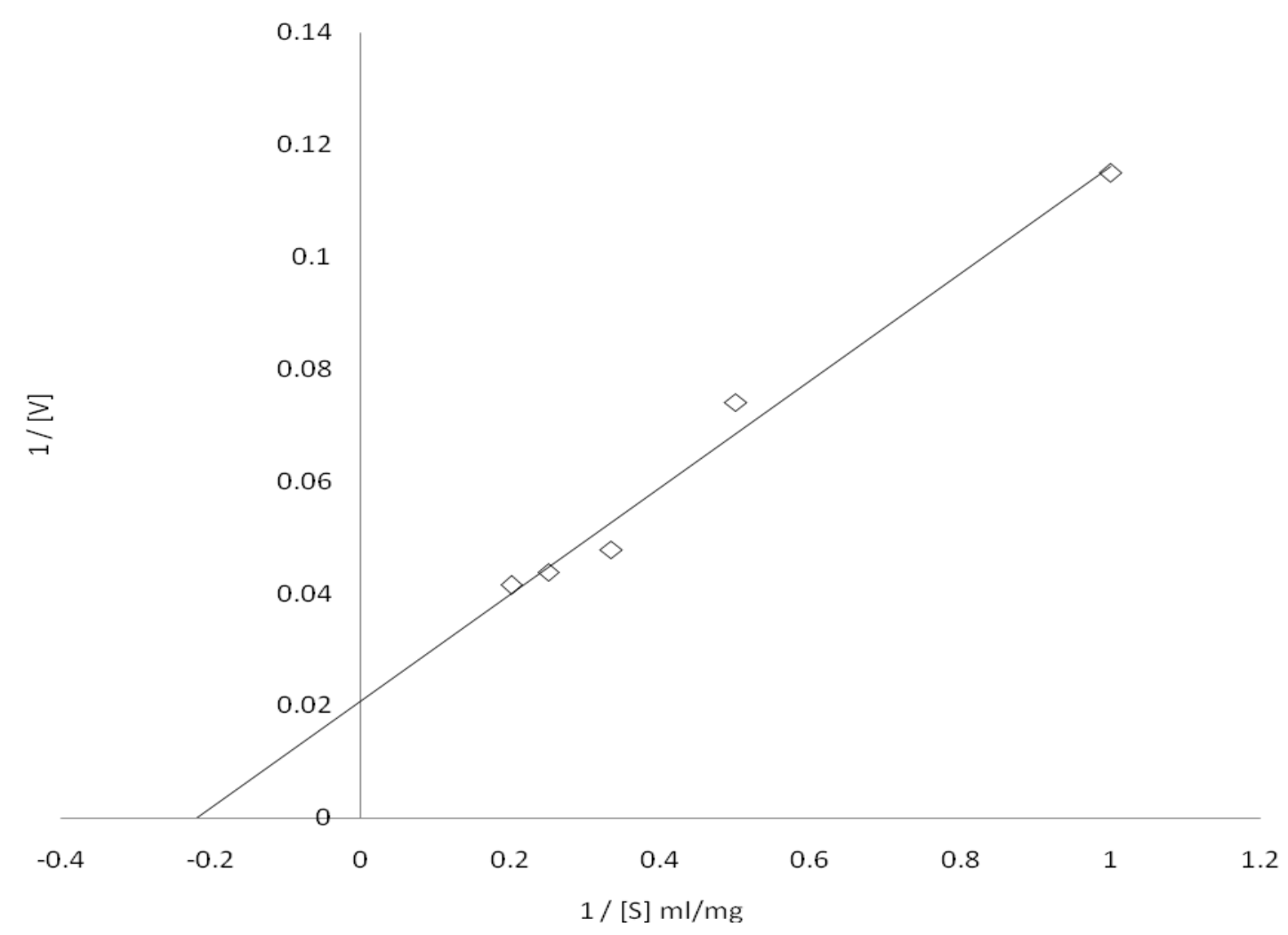

Figure 5. Lineweaver- Burke plot $\beta$-amylase produced by Bacillus sp.

Table 3. Effect of salts on $\beta$-amylase activity of Bacillus sp.

\begin{tabular}{|lc|}
\hline Salt & \% Relative activity \\
Control & 100 \\
$\mathrm{NaCl}$ & 101 \\
$\mathrm{CaCl}$ & 105 \\
$\mathrm{EDTA}$ & 103 \\
$\mathrm{MgCl}_{2}$ & 79 \\
$\mathrm{HgCl}_{2}$ & 53 \\
$\mathrm{FeCl}_{2}$ & 36 \\
\hline
\end{tabular}

\section{Discussion}

The proximate analysis of the carbon source; kola nut (Cola acuminata) revealed high percentage of carbohydrate (67.49\%) which was comparable with 69\% reported by Arogba (1999). However, Jayeola (2001) reported a carbohydrate content of $88.10 \%$. The $\beta$ - amylase was purified 6.40 -fold with $42.16 \%$ yield. The low purification factor may be due to the presence of low amounts of other proteins to be separated. However a single major activity peak of the $\beta$ - amylase was found in the elution profile during gel filtration on Sephadex G-150. The molecular mass of the purified enzyme was estimated as $39.4 \mathrm{kDa}$. Obi and Odibo (1984) reported a lower molecular mass of $31.6 \mathrm{kDa}$ for $\beta$ - amylase of an Actinomycete sp. however $\beta$ - amylase of high molecular weight have been reported in some other sources. Ray (2000) reported $209 \mathrm{kDa}$ and $105 \mathrm{kDa}$ for $\beta$ - amylase from Bacillus megaterium while Olaniyi et al.(2010) reported a molecular weight of $69 \mathrm{kDa}$ for $\beta$ - amylase of Volvariella volvacea. The 
$\beta$ - amylase showed maximum activity at $\mathrm{pH} 5.0$, thus exhibiting similarity to most $\beta$ amylase that have acidic $\mathrm{pH}$ optimum ranging from 4.5-6.2 (Mikami et al., 1982). Obineme et al. (2003) and Olaniyi et al. (2010) reported similar $\mathrm{pH}$ optimum of 5.0 for the $\beta$ - amylase of Aspergillus niger and Volvariella volvacea respectively. Sarowar et al. (2009) reported a pH optimum of 6.0 for the $\beta$ - amylase of Raphanus sativus root.

The temperature and thermal stability studies showed that the activity of the enzyme was optimal at $50^{\circ} \mathrm{C}$. This is a widely reported attribute of $\beta$ - amylase. Shinke et al. (1974) reported 50 to $60^{\circ} \mathrm{C}$ as optimum for the activity $\beta$ - amylase of Streptomyces sp. The enzyme retained $70 \%$ of its activity after incubation at $60^{\circ} \mathrm{C}$ for $60 \mathrm{~min} . \beta$ - amylase isolated from Curculigo pilosa was also reported by Dicko et al. (1999) to have an optimum temperature $55^{\circ} \mathrm{C}$ and retained $80 \%$ of its activity after incubation at $65^{\circ} \mathrm{C}$ for $90 \mathrm{~min}$. Denaturation of enzyme protein at temperature higher than $70^{\circ} \mathrm{C}$ has been reported by Gupta et al. (2003). Inactivation due to heat has been associated with a two-step process (Creighton, 1990). The reversible thermal unfolding of an enzyme as a result of increase in vibration and rotational motion of reacting molecules, which may also lead to dissociation in case of multi-subunit enzyme (Gupta et al., 2003). According to Daniel et al. (1996), extremely high temperature could also lead to deamination of asparagines and glutamine residues, hydrolysis of the peptide bonds at aspartic acid residues, thiol disulphide interchange and destruction of disulphide bonds and oxidation of amino acid side chains of protein molecule of the enzyme.

The affinity of the enzyme for the substrate was investigated using soluble starch as substrate. The $\mathrm{K}_{\mathrm{m}}$ and $\mathrm{V}_{\max }$ value of the purified Bacillus subtilis $\beta$ - amylase obtained from the Lineweaver-Burk double reciprocal plot was $5 \mathrm{mg} / \mathrm{ml}$ and $50 \mathrm{U} / \mathrm{mg}$. This is closely related to the $\mathrm{K}_{\mathrm{m}}$ value of $5.9 \mathrm{mg} / \mathrm{ml}$ of Alfalfa (Medicago sativa) root $\beta$ - amylase reported Douglas et al. (1982). The activity of the partially purified $\beta$ - amylase was enhanced by $\mathrm{Na}^{+}, \mathrm{Ca}^{2+}$ and ethylene diaminetetra acetic acid (EDTA). This observation is similar to those obtained for $\beta-$ amylase from other sources (Obi \& Odibo, 1984; Sarowar et al., 2009). However, the activity of the enzyme was inhibited by $\mathrm{Mg}^{2+}, \mathrm{Fe}^{2+}$ and $\mathrm{Hg}^{2+}$. Heavy metals are known to react with protein sulphydryl groups, thus converting them to mercaptides (Dixon \& Webb, 1971). Hydrolytic degradation of disulphide bond by mercury has also been reported (Whitaker, 1972).

\section{References}

A. O. A. C. (1984). Association of Official Analytical Chemistry. Official methods analysis, $14^{\text {th }}$ Edition.

Arogba, S. S. (1999). Studies on kola nut and cashew kernels; Moisture adsorption isotherm, proximate and functional properties. Food Chemistry, 67(3), 223-228. http://dx.doi.org/10.1016/S0308-8146(99)00095-3

Boldon, M. \& Effront, P. (2000). Microbial amylolytic enzymes. Critical Review Biochemistry Molecular Biology, 24, 329-418.

Bernfield, P. (1955). Amylases and methods. Enzymology 1, 147-154. 


\section{MInstitute Macrothink}

Journal of Biology and Life Science ISSN 2157-6076 2013, Vol. 4, No. 1

Chang, A., Kim, J. Y. \& Hyum, O. A. (1996). Purification and characterization of alkaline cellulase from newly isolated alkalophilic Bacillus species. Biotechnology, 27, 313-316.

Creighton, T. E. (1990). Protein Function: A practical approach. Oxford University Press, Oxford 306.

Daniel, R. M., Dines, M. \& Petach, H. H. (1996). The nature and degradation of stable enzymes at high temperatures. Biochemistry Journal ,317, 1-11

Dicko, M. H., Searle-van Leeuwen, M. J. F., Beldman, G., Ouedrago. O. G., Hilhorst, R. \& Traore, A. S. (1999). Purification and characterization of $\beta$ - amylase from Curculigo pilosa. Appl. Microbiol. Biotechnol,52, 802-805. http://dx.doi.org/10.1007/s002530051595

Dixon, M. \& Webb, E. C. (1971). Enzymes. $2^{\text {nd }}$ Edition, William Clowes and Son, London. 950 .

Douglas, C. D., Doehlert, S. H. \& Laurens, A. (1982). Beta-amylases from alfalfa (Medicago sativa L.) roots. Plant Physiol,69, 1096-1102. http://dx.doi.org/10.1104/pp.69.5.1096

Fogarty, W. M. \& Kelly, C. T. (1980). Amylases, Amyloglucosidase and related Glucanases. In: Microbial enzymes and Bioconversion $4^{\text {th }}$ Edition Academic press, London, 115-170.

Gupta, R., Gigras, P., Mohapatra, H., Goswami, V. K. \& Chauhan, B. (2003). Microbial alpha amylase: a biotechnological perspective, Process Biochemistry 38, 1599-1616. http://dx.doi.org/10.1016/S0032-9592(03)00053-0

Jayeola, C.O. (2001). Preliminary studies on the use of Kola nuts (Cola nitida) for soft drink production. J. Food Technol. Afr, 6(1), 25-26. http://dx.doi.org/10.4314/jfta.v6i1.19280

Lowry, O. H., Rosebrough, N. J., Farr, A. L. \& Randall, R. L. (1951). Protein measurement with folin phenol reagent. J. of Biol. Chem, 193, 265-273.

Mamo, G., Gashe, B. A. \& Gessesse, A. (1999). A highly thermostable amylase from a newly isolated thermophilic Bacillus sp. WN11. J. of Appl. Microbiol, 86, 557-560. http://dx.doi.org/10.1046/j.1365-2672.1999.00685.x

Mikami, B., Aibara, S. \& Morita, Y. (1982). Distribution and properties of soybean $\beta$ - amylase isozymes. Agric. Biol. Chem, 46, 943-953. http://dx.doi.org/10.1271/bbb1961.46.943

Obi, S.K.C. \& Odibo, F.J.C. (1984). Partial purification and characterization of a thermostable Actinomycete $\beta$ - amylase. Appl. Environ.Microbiol, 47(3), 571-575.

Obineme, O.J., Ezeonu, M.I., Moneke, A.N. \& Obi, S.K.C. (2003). Production and characterization of an alpha amylase from an Aspergillus oryzae strain isolated from soil. Nig.J. of Microbiol, 17(2), 71-79.

Olaniyi, O. O., Akinyele, B. J. \& Arotupin, D. J. (2010). Purification and characterization of beta amylase from Volvariella volvacea. Nig. J. of Microbiol, 24(1), 1976-1982.

Oudjeriouat, N., Moreau, Y., Santimone, M., Svensson, B., Marchis-Mouren, G. \& Desseaux, V. (2003). On the mechanism of $\alpha$-amylase: Acarbose and cyclodextrin inhibition of barley 
amylase isozymes. Eur. J. Biochem. FEBS, 270, 3871-3879. http://dx.doi.org/10.1046/j.1432-1033.2003.03733.x

Pandey, A., Nigam, P., Soccol, C. R., Soccol, V. T., Singh, D. \& Moham, R. (2000). Advances in microbial amylases. Biotech. Appl. Biochem, 31, 135-152. http://dx.doi.org/10.1042/BA19990073

Rani, T., Takagi, T. \& Toda, H. (2007). Bacterial and mold amylases.Pp. 235-271. In: Boyer, P. (ed.). The enzymes. Academic Press Inc., New York.

Ray, R. R. (2000). Purification and characterization of extracellular $\beta$ - amylase of Bacillus megaterium B6. Acta Microbio. Immunol, 47, 29-40.

Reddy, N. S., Annapoora, N. \& Sambawa, R. K. (2003). An overview of the microbial alpha amylase family. Afr. J. of Biotech, 2(12), 645-648.

Sarowar, M. G., Shaela, M., Rowshanal, M., Farjana, N. \& Habibur, M. (2009). Purification and characterization of $\beta$ - amylase from Raddish (Raphanus sativus L.) root. J. of Appl. Sci. Res, 5(12), 2225-2233.

Shinke, R., Nishira, H. \& Mugibayashi, N. (1974). Isolation of $\beta$ - amylase producing microorganisms. Agric. Biol. Chem, 38, 665-666. http://dx.doi.org/10.1271/bbb1961.38.665

Whitaker, J.R. (1972). Principles of Enzymology for the Food Sciences $5^{\text {th }}$ Edition. Marcel Dekker, Inc. New York 63pp.

\section{Copyright Disclaimer}

Copyright reserved by the author(s).

This article is an open-access article distributed under the terms and conditions of the Creative Commons Attribution license (http://creativecommons.org/licenses/by/3.0/). 